https://doi.org/10.15407/scin16.01.088

MOHAMMADREZA SHARIFIBAMROOD ${ }^{1}$ and MAJID MAFI ${ }^{2}$

Trauma Research Center, Baqiyatallah University of Medical Sciences, Nosrati Alley, Sheikh Bahai South Avenue, Mollasadra Street, Vanak, Tehran, Iran, +989 153165943, +989122017725, Majid.mafi@gmail.com

\title{
DESIGNING AND MANUFACTURING THE ARAD RESCUE ROBOT AND EVALUATING ITS EFFICIENCY FOR USAR MISSIONS
}

Introduction. Every year, natural disasters such as earthquakes, floods, and storms occur around the world and many people die as a result of the devastation. In the relief and rescue operations, many injured people may lose their lives as they remain under the rubble for hours and even days because rescue agents have no access to them.

Problem Statement. One of the major problems for rescuers is overcoming and removing obstacles on the path for quick access to injured people.

Purpose. To study the process of designing the Arad rescue robot for urban search and rescue (USAR), to define the robot tasks, and to design suitable mechanisms for their fulfillment. The general purpose is to design and to build a rescue robot with a high speed and precision and a low cost in order to better find the injured people under the rubble.

Materials and Methods. To complete the design method, CATIA software was used to apply the finite element method for powerful analysis of complicated parts. Also, Solidworks was used to model the mechanisms, where $3 D$ sketch of each component of the robot was generated by means of it. Finally, the components are convened together with controlling hardware. Two central processors are used within the control system of the robot. The director's PC as the master processor and the laptop installed on the robot as the vassal processor. The general design of the robot has been performed using the SOLIDWORK modeling software while to design the robot arm, CATIA software is employed so that the manipulator motion analysis is made in this software in addition to using the software modeling power. In order to pass obstacles and impassable routes, a caterpillar has been used in the robot motion system and also, two arms have been embedded in the front part of the robot to climb obstacles and rugged terrains.

Results. In addition to the rotating arm, one skilled arm has been designed for robot to overcome these problems. In addition, the use of sand wheels has forced the robot to increase its ability to travel on different routes.

Conclusions. Different national and international competitions have provided an opportunity for this robot to display its capabilities in an environment close to the real conditions. The robot has been awarded with many titles, which testifies to a great success and actual improvements in every aspect. The performance of this design and build has been shown in the Rescue Robots League and appreciated as one of the best designs.

Keywords: Rescue robot, arm, urban search and rescue (USAR) missions.

Цитування: Mohammadreza Sharifibamrood and Majid Mafi. Designing and Manufacturing the Arad Rescue Robot and Evaluating Its Efficiency for Usar Missions. Nauka innov. 2020. V. 16, no. 1. P. 88-99. https:// doi.org/10.15407/scin16.01.088 
Every year, natural disasters such as earthquakes, floods, and storms occur around the world and many people die as a result of the devastation. In the relief and rescue operations, many injured people may lose their lives as they remain under the rubble for hours and even days because rescue agents have no access to them [1]. Search and rescue (SAR), and also urban search and rescue (USAR) operations are important and often dangerous relief operations. Modern technology can significantly improve the speed and safety of these operations. Search and rescue operations for lost people are often in natural areas such as forests and mountains. To discover the area where a person has been lost, robotic technology can be faster and cheaper than sending a human search team or a helicopter [2]. USAR is an emergency response to a natural or human disaster, such as an earthquake or a terrorist attack, which destroys urban structures and buries people under heavy and unstable rubble. In this scenario, a USAR team will be deployed to the disaster site in order to find the victims, pull them out and give them first aid. Robotic technology is one of the most useful USAR aids since a robot enters places that can be unsafe for a human being [3]. Loose rubble, impassability of the path for the passage of the officials and failure to accurately identify the location of the injured are among the factors that cause the lack of access to the injured and delay in relief and rescue operations [4]. A robot can be sent to the exploration area, identify the place of the victims, establish a communication channel with them and carry items like water, snacks and blankets. Robotic technology is also examined for marine search and rescue operations in order to be effective and in fact, these operations are for the victims of the ships that have sunk near the coast [5]. Urban search and rescue operations are highly sensitive to time and mistakes and impose a lot of stress and physical and mental fatigue on the team. It seems that technology is a clear choice to help the USAR team and performs this operation more effectively. However, this is a very difficult task for designers of this technology. Thus, in USAR operations, there are very few changes due to uncertainty in the technology or the cognitive demands presented to the operator. In other words, a great responsibility has been shouldered by the technology designers to make it perfectly suited to the USAR domain or otherwise, it is immediately rejected by the users. Technology for USAR is useful at various practical stages: Obtaining preliminary information about the status of the environment, searching for victims and preparing the saved and liberated victims while supporting them [6]. Many of the technologies considered for USAR have been designed with regard to the search step. This is an important step to focus on it because the safety of the USAR team members is a top priority and as long as the supported structures are not built, for the team's entry into buildings to visit the victims, it should be made sure that they have been safely prepared for the entry and search for the survivors. This delays the rescue process, which can potentially lead to the survival of the victims. Nevertheless, robotic technology can be made available and can be allowed to start the search before building a stabilizer to explore the survivors and ultimately securely entering the insecure environment [7]. When a robot is sent to search for the survivors buried under the rubble, if the environment where it has entered is sufficiently secure, a search and rescue specialist will be replaced. Indeed, the operator can practically explore the environment through a robot from a remote distance while being in a completely secured place (extend this feeling to stone ruins or a place with hazardous substances) [8]. Probably the best achievement can be the focus on user interface to create telepresence (an experience of presence in an environment through technology and the real physical experience of that environment) [9]. Search and rescue forces are using some technologies, such as some robotic technologies that help them in the search section [10]. However, many of the robotic technologies currently used in urban search and rescue are taken from other areas, like building cameras or life detec- 


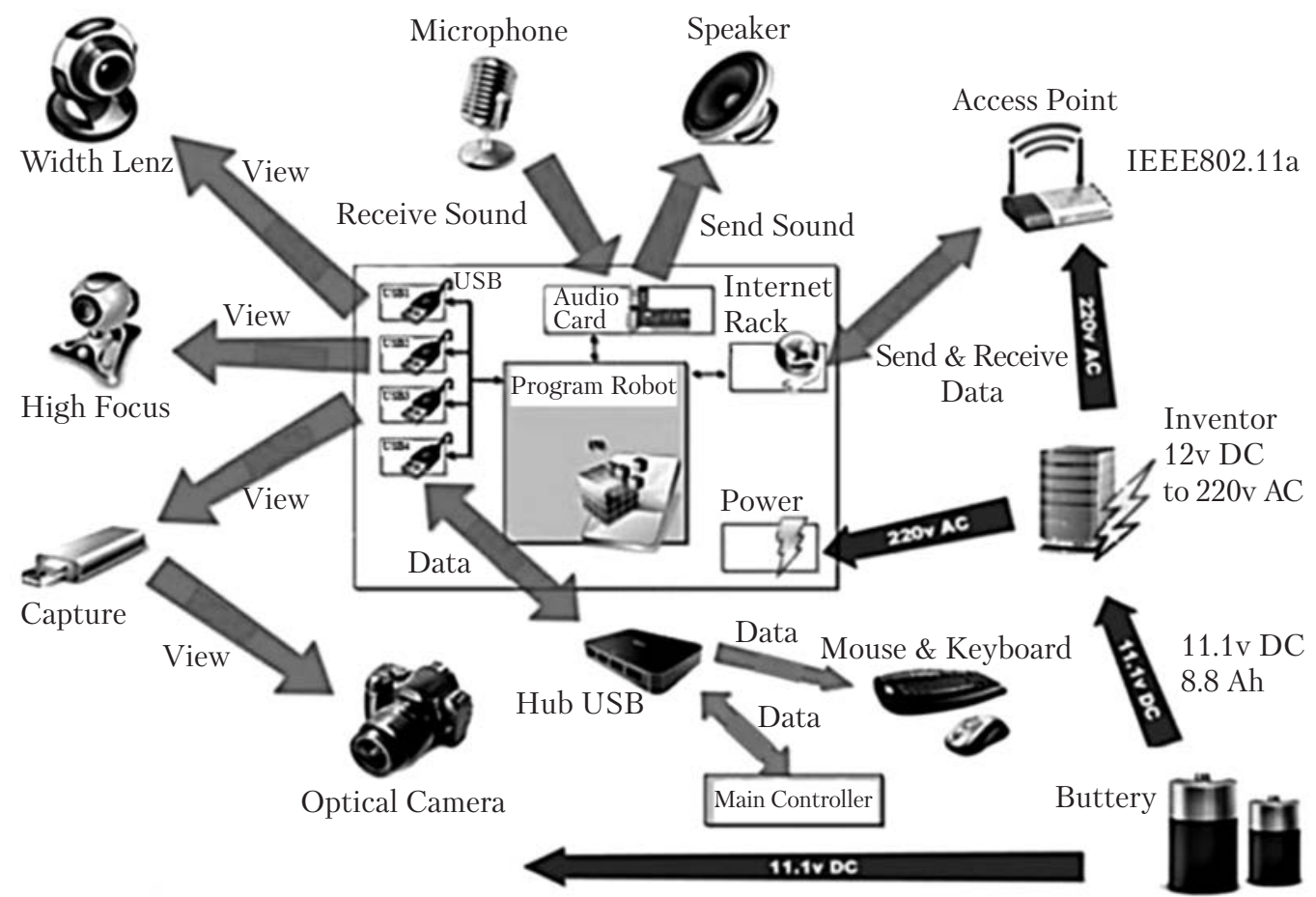

Fig. 1. Schematic design of rescue robot tools and sensors

tors, and hence are not fully compatible with the search and rescue environment and certainly, a design is required based on the qualitative parameters desired by the stakeholders [11]. To this end, robotics professionals prepare the ground for accelerating assistance to the injured by designing and building rescue robots. A rescue robot is a robot that enters the environments in which an incident has happened and sends information on the coordinates and specifications of the injured to its control unit. The purpose of the construction of a rescue robot is to build robots with high speed and precision and low cost in order to better find the injured under the rubble [12].

It is crucial to select the mechanism of rescue robots due to the impassability of the path of their movement and many efforts have been made to achieve optimal motor mechanisms [13].

\section{HOW TO ESTABLISH COMMUNICATION}

The schematic design of rescue robot tools and sensors is guen in Fig. 1. The communication path between the robot and humans is very important in the USAR missions because in the event of disconnection, access to the robot is not possible. Therefore, various protocols have been provided for rescue robots depending on the circumstances.

These protocols include wired and wireless types. Wireless protocols are usually applied for radioactive conditions and the conditions in which there is noise and disruption in waves although the main problem with this method is the presence of cable, carrying it and getting caught in the path.

Communication protocol of Arad rescue robot with the operator is through a wireless network with standard $5 \mathrm{GHz}$ (IEEE 802.11a). Information such as robot control data, images, sensors data and so on is transmitted in this way. It is worth noting that the above-mentioned information is transmitted through a program that is defined and installed on the robot. This program has capabilities such as data transfer through the communication network and establishment of 
hardware communication between the computer on the robot and electronic circuits.

The most important advantage of this program is the transmission of information in very low volumes, which causes to increase data transfer speed. For example, in IP and CCD cameras, the time delay of 1 to 2 is reduced to 0.2 with this program. The robot has the ability to connect to the Internet through a wireless network (Wi-Fi), which makes it possible to communicate with the robot from any point.

In new methods, two navigators are used simultaneously to control the robot, which employ optimal protocols and point out the importance of communication between the robot and the navigator [14].

\section{METHOD OF CONTROL AND COMMUNICATION BETWEEN HUMANS AND ROBOTS}

Although the application of automated robots that facilitate the performance of operations for the navigator using heat, light and gas sensors and route scanning is widespread, the main tasks are still undertaken by the navigator.

The rescue robot control diagram is shown in Fig. 2.

Burke and colleagues proposed to develop a new detection model for better understanding of the environment from a robot's perspective [15].

To connect the operator to the robot computer, it is necessary for the robot internal program to

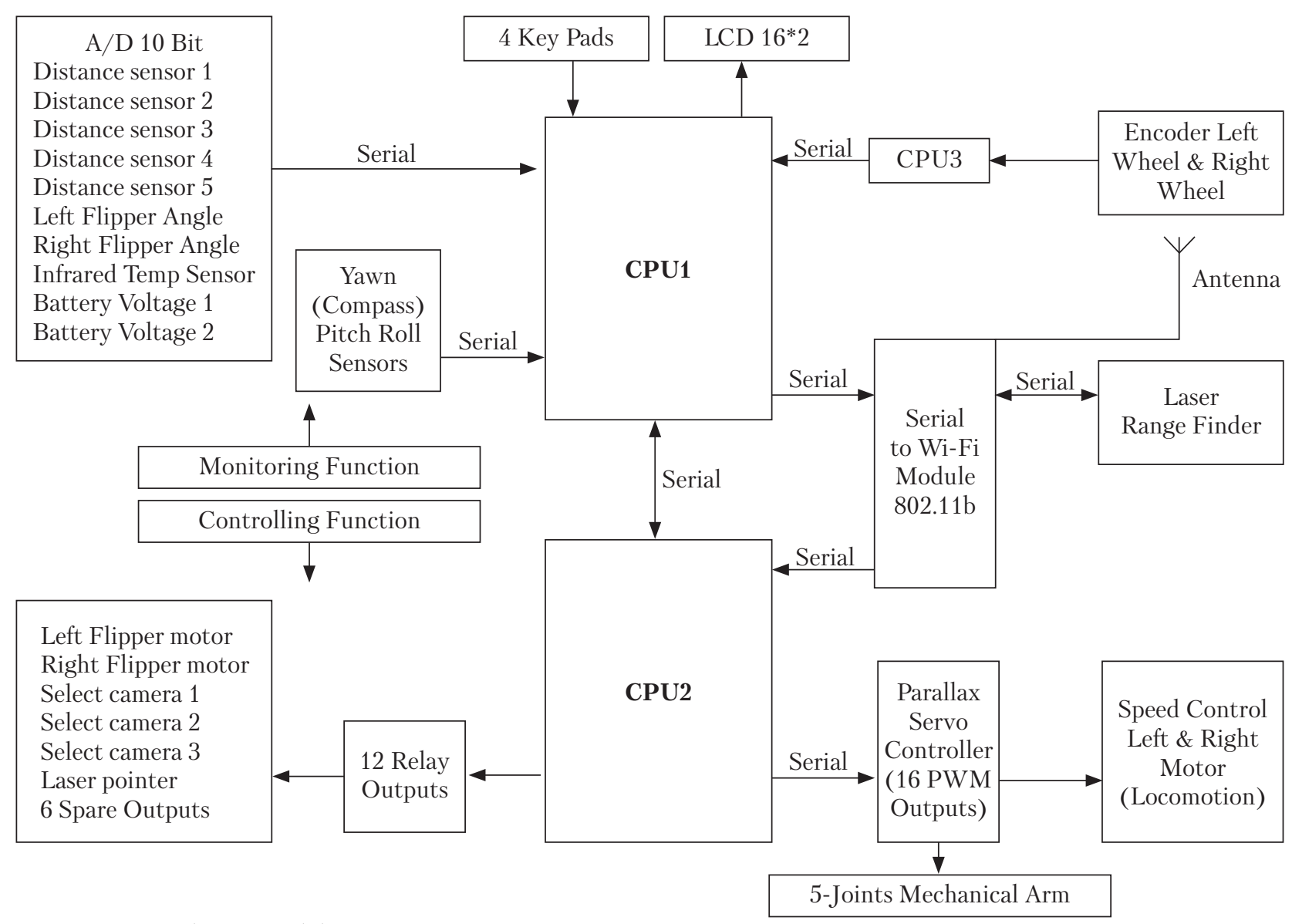

Fig. 2. Rescue robot control diagram 


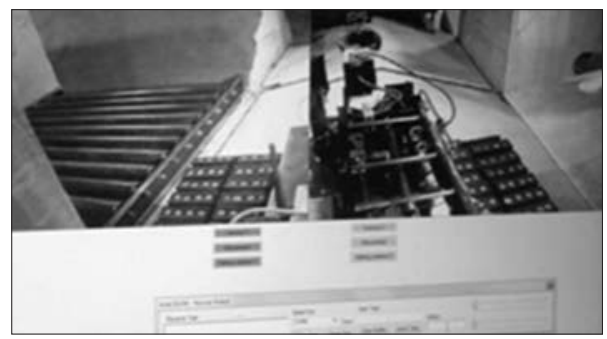

Fig. 3. The image sent by the rescue robot

install a program automatically on the operator's computer; this program provides the operator with data from the robot address in the network. For the operator to communicate with the robot computer, it is necessary that the operator be aware of the robot internal program security code. Having this security code, the operator is able to communicate with the robot using any computer and control it, and it is just necessary to match the sent instructions of the program with the controller keys. This issue prevents the operator limitation in control of the robot by just a specific controller. The robot control program has the ability to capture all images along with incoming and outgoing information. Among the robot control tools, we can refer to keyboard, mouse, joystick and so on [16].

An example of image obtained from rescue robot is given in Fig. 3 .

However we should consider that the use of user interfaces existing in video games can have a more favorable effect on training the application of USAR robots for users because most people have a history of familiarity with computer games and also, user interfaces can play a crucial role in reducing navigator stress during operations relative to complex user interfaces and decrease human errors.

Although the use of distance measurement sensors, laser and cursor sensors and the sensors with similar capabilities facilitates the navigator's work, the application of camera and video communication has its own advantages.

Using multiple cameras or a Panomera camera provides a fairly useful view for the user. But the use of a camera whose directions and height can be changed can provide a better view for the user.
Thus, rescue robots have been pushed to using robotic arms.

Using the image processing method when performing operations can be very effective and the subtle points that may be ignored by the sensors due to overlapping or be overlooked by the navigator for various reasons can be identified and announced, which requires the application of appropriate algorithms that become upgraded day by day.

\section{MECHANICAL PARTS}

In a rescue robot (Fig. 4), the more complete is the main mechanism, the smoother is the robot motion. The main mechanism consists of two parts: motion mechanism and rotating arm mechanism of the robot. Since these two mechanisms are completely interdependent and cannot be differentiated, they are part of the main robot mechanism [17].

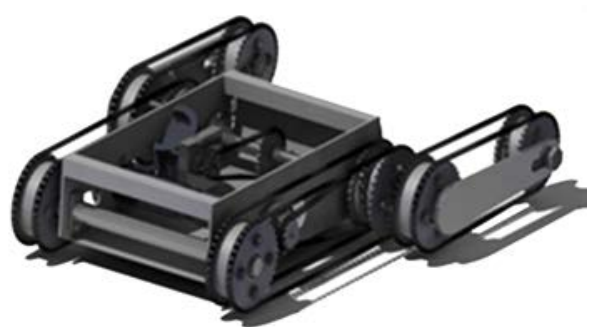

Fig. 4. 3-D model of the rescue robot

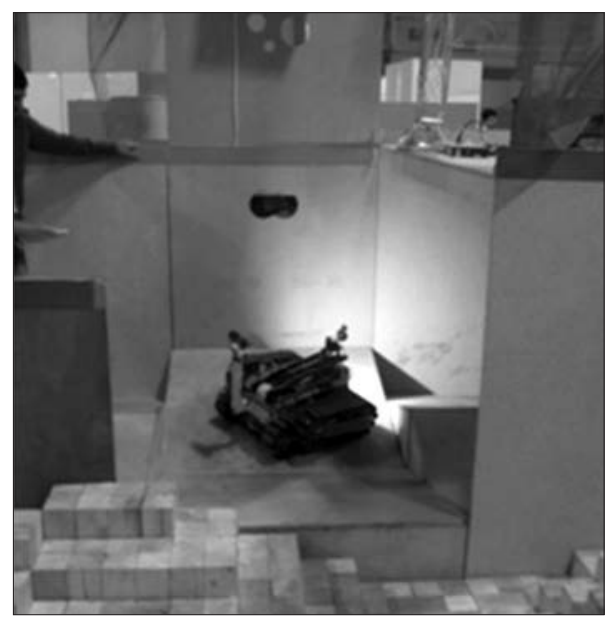

Fig. 5. Testing the rescue robot in the racing track 
The robot is actually modified in three stages of construction and practical testing (Fig. 5), as in the early version, the robot lacked a front arm, and a single chain was used, given a high pressure and tear of the chain. In the next version, the robot was modified and the same way in the final version, with additional front arm, with the ability to move objects added for more accurate search operations.

\section{ROBOT ACTUATOR SYSTEM}

Movement of a robot in different routes depends entirely on this system. This system transforms the power of motors transmitted by the power transfer system into a proper and secure motion. All chassis and body systems are designed and engineered using the solid works premium 2014 software and all arm parts using the CATIA V5 software, as well as manufacture plans in CATIA software. Selection of a proper mechanical mechanism for this system can ensure a coherent motion for the robot. For the robot actuator system, a gear and chain mechanism was used (Figs. 6-7). One reason for the application of this mechanism is the greater strength and power of the gear and chain mechanism relative to the belt and pulley mechanism. The robot actuator system is composed of four axes of gears and chains that are located two by two on both sides of the robot so that the left axes are independent of the right axes and their movement does not interfere with each other [18]. Each of the actuator systems consists of two rows of chains and corresponding to each of the rows, one gear is rotating in the front part of the robot and one gear on the rear shaft of the robot. For the free rotation of this gear pack, it is necessary to place two ball bearings in the space between the pack and the rear shaft of the robot and given that the rear shaft of the robot is fixed and connected to the robot body, the gear pack rotates around the fixed axis of the rear shaft. In the front part of the robot, there is a sheath which is connected to the robot body. The robot actuator arms shaft that

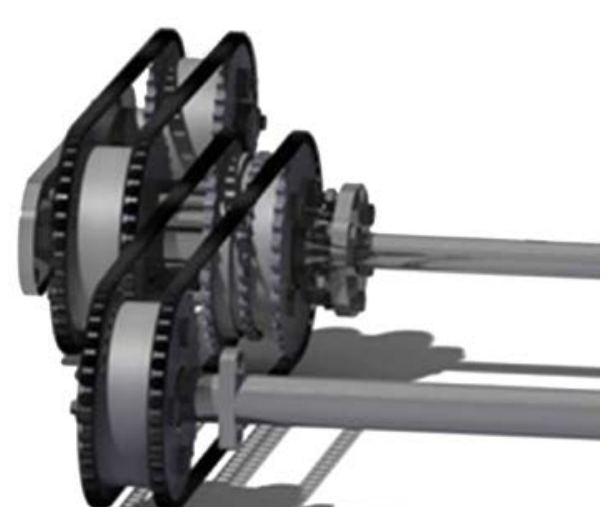

Fig. 6. 3-D model of the rescue robot actuator system

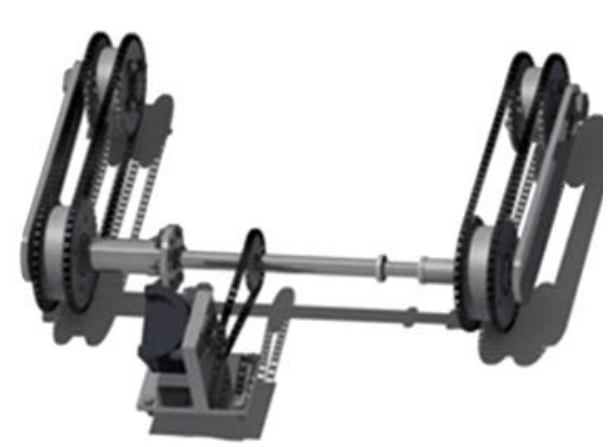

Fig. 7. 3-D model of the recue robot actuator arm

provides the rotational motion of the arms passes through this sheath and to facilitate the movement of this shaft inside the sheath, the space between the sheath and the shaft is filled with four ball bearings.

The sheath in the front part of the robot acts as a fixed shaft and consequently, the pack corresponding to the robot rear gear pack, which is placed in the front part of the robot, rotates around the sheath axis. The robot front gear pack includes 2 gears on both sides of the retaining part and one gear in the middle of the retaining part; the gear in the middle is part of the power transfer system which will be explained in the following. The space between this pack and the sheath in the front part of the robot is filled with two ball bearings for free movement of the pack around the sheath axis [19]. In addition to this gear pack, another gear pack that belongs to the 


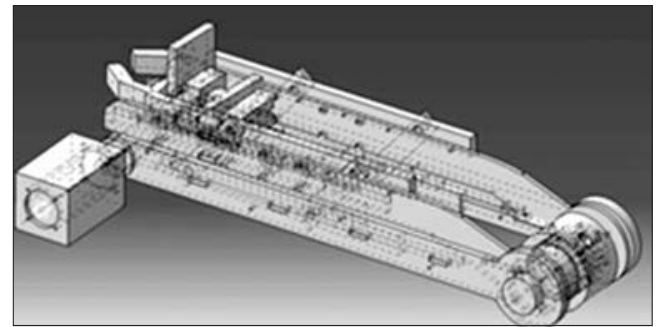

Fig. 8. 3-D model of the rescue robot manipulator

robot arm actuator system is on this sheath and like the previous pack, the space between the pack and the front sheath is filled with two ball bearings. In order for the motion of the robot main actuator system to be coordinated with the motion of the robot actuator arm system, the force transmitted by the power transfer system from the motor to the gears must be divided between the gears on the sheath in the front part of the robot. For this purpose, the gear pack of the main actuator system was coupled with the gear pack of the arm actuator system so that the transmitted force, in addition to actuating the main actuator system, also propels the arm actuator system.

It is clear that since the gears movement in two systems is in one direction, movement of the actuator systems will be also in one direction; that is, if the main actuator system moves forward, the arm actuator system also moves forward due to the coupling of two gear packs on the front sheath.

In this system, the size of the rear gear pack and two front gear packs was considered to be the same; i.e. radiuses of gears in the rear gear pack, front gear pack and arm gear pack were selected to be completely equal and based on the equality of the gears, the retaining parts between the gears should also be similar. It should be noted that the gear in the middle of the retaining part of the front gear pack, which played a role in the power transfer system, should be of a smaller radius compared to other gears so that while moving, the chain attached to this gear does not interfere with the movement of the main actuator system chains [20]. Here, the crucial point is the complete coordination of each of the gear packs; that is, when two gears are placed on both sides of the retaining part, teeth of the two gears should be in the same direction. This is important because lack of coordination between the teeth causes inconsistency of the chains on the two gears, resulting in difficulty in the robot movement.

In connection with the material of the sheath in the front part of the robot and the shaft in the rear part, it was decided that these two pieces be made of the Mo40 steel, like the robot arm rotating shaft. This choice has a close relationship with the strength of these parts. Since the forces acting on the robot enter these parts after the actuator system and the gears, selection of materials that would provide the required strength was put on the agenda. Other parts of the robot actuator system were produced from the same materials as described in the previous two sections.

\section{ROBOT ACTUATOR ARM}

Perhaps one of the most sensitive and important parts of the robot is its actuator arm (Fig. 7). In terms of the type of robot structure, the actuator arm plays a decisive role in robot movements in the face of barriers. As a result, efficient arm design can greatly help the robot motion. The robot actuator arm is mechanically such that it has a 360-degree rotation and also an actuator system. The 360-degree rotational movement of the arm is such that in the part jointed to the robot body, the arm creates a 360-degree rotation around that joint. The arm actuator system is a system integrated with the main actuator system of the robot. This means that no separate motor has been used for the arm actuator system. The same motor that drives the main actuator system is connected, in an integrated manner, to the arm actuator system by the mechanism described in the following sections and causes the system to move. In the final design of the robot, two actuator arms have been anticipated that are in the front part of the robot. In terms of rotational motion, the two arms are fully coordinated. These two arms are coupled by a long shaft that connects to the other 
arm from one side of the robot and by going through the robot width on the other side of the robot. This shaft, using its motor and mechanism, provides the rotational motion for the actuator arm so that the rotation rate of the robot left arm is in perfect harmony with the right arm. The arm actuator system includes a gear and chain system such that there are two gears in the lower part of the arm and the same structure is in the upper part of the arm. Moreover, two rows of chains embedded on these gears make up the arm actuator system. Unlike what causes the rotation of the robot's two arms, in this part, each of the actuator systems moves independently and their motion is provided by the motor that drives the main actuator system. Notably, the main actuator system on both sides of the robot is powered by two separate motors. Therefore, robot actuator systems are completely independent of each other. The main body of the arm, in addition to playing the role of maintaining the integration of the arm mechanics, should have high resistance in order not to be damaged in dealing with obstacles. The main body of the arm with an integrated structure is designed in a way to be coupled with the rotating shaft of the arm in the lower part and, in the upper part, control the axis of the gear system in the upper part of the robot arm or, in other words, the gear pack in the upper part of the robot arm.

In the upper part of the main body of the arm, a groove was created for the movement of this axis so that the gear pack axis can adjust the stiffness or looseness of the chain by moving in this groove. Gear packs in the actuator arm are quite similar. These packs are made of two gears that are located on either side of a specific part. The packs are placed by two ball bearings on the upper and lower axes of the arm so that the movement of the packs around the mentioned axes becomes a loose and smooth motion. Using this mechanism helps that when the gear pack of the lower arm axis starts to moves, the gear pack of the upper axis also moves in a coordinated and smooth manner. The main body of the actuator arm and the main shaft of the two arms are made of mo40 steel alloy. Some of the reasons for this choice are as follows:

1 - Durability and high strength of these steels in high-stress environments with regard to their volumetric mass;

2 - The ability to properly produce and manufacture the parts;

3 - High frequency of use of this metal in the industry.

As to the arm gear pack, gears made of hardened iron were selected mainly because of high strength against bearing stresses applied by the chains. In this pack, in addition to gears, another piece is also used which is made of Teflon and has the role of retaining the gears and also integrating and coordinating them. The reasons for choosing this material include its high pressure tolerance and lightness, leading to the strength and lightness of the gear pack.

Considering that the robot size is of great importance to us, attempt was made to select highstrength raw materials so that if the dimensions of the parts used in the robot became small, its overall strength and resistance are not reduced. Accordingly, the main shaft of the robot actuator arms became small to the extent that its strength is not reduced and does not get close to the danger zone. The next point was the torque resulting from the weight of the actuator arm and the gear pack of the axis in the upper part of the arm on this shaft. As a result, to reduce the torque, the radius of the gears in the gear pack of the upper axis was selected to be smaller than the radius of the corresponding gears in the lower gear pack and also, choosing Teflon as the retainer of the two gears greatly helped achieve this goal. In relation to the main body of the arm, attempt was made to reinforce this process of lightening through producing a special shape design and also decreasing its thickness as much as possible.

\section{ROBOT MANIPULATOR}

This arm should provide the robot with the ability to remove and displace objects. Hence, in ad- 


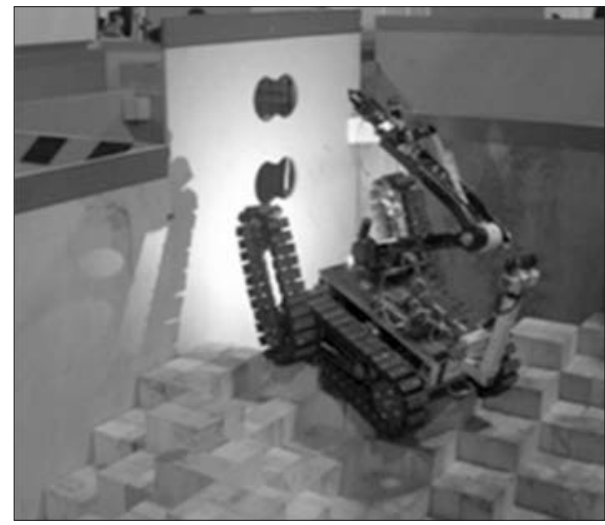

Fig. 9. Detection of injured people by rescue robot

dition to the ability to maneuver in all directions, it should be capable of removing and displacing objects with different weights [21]. For the manipulator (Fig. 8), a mechanism similar to that of the camera arm was designed, with the difference that instead of the camera, a sliding handler that is closed by the arm servomotor is used in this arm. This servomotor creates a sweep movement in the sliding handle by performing clockwise and counterclockwise motion.

To meet the capability of removing objects with different weights, the use of more robust servomotors and also more resistant raw materials was put on the agenda so that this arm does not bend when removing objects and eventually a fracture is not created in the bending area after repeating this action several times. Besides, the servomotors used should have the ability to be placed in the lock status when removing objects and do not rotate a bit out of the desired state because the smallest rotation of these servomotors will cause the arms to fall, resulting in the falling of the object.

Considering that a high-degree of freedom arm was needed in the skilled arm's position, the following formula was used to the arm with the required degree of freedom was designed:

$$
\begin{gathered}
d o f=m(N-1)-\sum_{i=1}^{j} c_{i}=m(N-1)-\sum_{i=1}^{j}\left(m-f_{i}\right)= \\
=m(N-1-j)+\sum_{i=1}^{j}\left(f_{i}\right) .
\end{gathered}
$$

Where $m=3$ for the flat mechanisms and $m=6$ for the space mechanisms, $N$ is the number of links, $J$ is the number of joints, and $f_{i}$ is the number of degrees of freedom of the $i$-th joint.

The main goal of the rescue robot is to cross impassable routes and to find possible injured people in various parts of the route [18] (Fig. 9). Search is the most important task of the USAR robot. Therefore, it is important to use the best method or combined methods for better searching. But the search in the real environment is very different from simulated environments. Consequently, finding the injured is more important than the robot movement in the racing track.

Usually a doll is used instead of the injured. The robot should have capabilities such as seeing the injured, detecting the amount of oxygen and carbon dioxide in the environment and recognizing the ambient temperature. For this reason, there are elements beside the injured that consider these capabilities. A sheet of element E, used to detect visual acuity, is put next to the injured person and the robot should recognize this element with its camera. A thermal element is also placed next to the injured person, which raises the temperature around the injured person above the ambient temperature and the robot should measure the temperature around the injured person with its thermal sensors. There is another element beside the injured, which stimulates oxygen and carbon dioxide sensors of the robot and changes the amount of oxygen and carbon dioxide around the injured. Elements described above are generally referred to as "the injured" in the tournaments and when it comes to finding an injured person, it is not just the physical location of the injured, and an examination of the elements beside the injured is also considered.

But what the robot can do when dealing with the injured is also important. Providing a bottle of water can restore the injured person. Further, oxygen release, if needed, and the use of the communication system between the injured and the navigator to increase the morale of the injured 
are very practical points at the critical moments in real operations.

Considering the type and structure of rescue robots, the process of using these robots is increasing. Because of their powerful mechanical structure and also the capability of remote control of robots, rescue robots are able to perform their duty at the scene of an accident in relief and rescue operations and help in finding the injured. In many of these events, the role of rescue robots is undeniable. Therefore, these robots gradually become an integral part of relief and rescue operations. Furthermore, the use of this kind of robots in special events, such as the recent tsunami in Japan which led to destruction of several nuclear power reactors in this country, becomes more and more evident. In this incident, rescue robots had a very important role in examining destroyed areas that were exposed to nuclear radiation. Additionally, they were very helpful in the operations in which humans could not be present due to radiation. Robots that are placed in the class of rescue robots, in addition to having numerous capabilities in searching for the victims of accidents, can also be used as military automatic drive systems. By understanding that the important industrial countries of the world have turned to using robots more than ever before, it becomes clear to us that in order to be an influential country in the future, we should take step in the direction of designing and manufacturing robots, including rescue robots, in a rapid and evolutionary process. The robot built in the first nationwide tournament did not get any title, but in the process of completing the design of the building in subsequent periods, while gaining superior positions, it was able to reach the injured with less damage to the robot's appearance at a faster time, and the robot could take on more difficult routes and More rugged. Designing and building robots such as real Arad rescue robot can be a serious and effective step in this respect. Due to the existing conditions and problems in supplying raw materials in Iran to manufacture the machine, the research led to the production of robots from light and inexpensive materials with acceptable and low cost, and the result of investigation of the research and development unit leading research the production of this robot at a cost was about USD 600 . Although this robot has many defects as a prototype, it should be remembered that a first version is not always the best and most complete version and if this movement continues, perhaps in the near future, we achieve a perfect example of a real rescue robot.

\section{REFERENCES}

1. Lima, P. U. (2012). Search and rescue robots: the civil protection teams of the future. In: 2012 Third International Conference on Emerging Security Technologies (EST). P. 12-19.

2. Bogue, R. (2016). Search and rescue and disaster relief robots: has their time finally come? Ind. Robot Int. J., 43, 138-143. doi:10.1108/IR-12-2015-0228

3. Casper, J., Murphy, R. R. (2003). Human-robot interactions during the robot-assisted urban search and rescue response at the world trade center. IEEE Trans. Syst. Man Cybern. Part B Cybern., 33, 367-385. doi:10.1109/TSMCB.2003. 811794

4. Yeong, S. P., King, L. M., Dol, S. S. (2015). A review on marine search and rescue operations using unmanned aerial vehicles. World Acad. Sci. Eng. Technol. Int.J. Mech. Aerosp. Ind. Mechatron. Manuf. Eng., 9, 396-399.

5. Murphy, R. R., Tadokoro, S., Kleiner, A. (2016). Disaster robotics. In: Siciliano, B., Khatib, O. (Eds.) Springer Handbook of Robotics. P. 1577-1604. Springer, Cham. doi:10.1007/978-3-319-32552-1_60

6. Statheropoulos, M., Agapiou, A., Pallis, G. (2015). Factors that affect rescue time in urban search and rescue (USAR) operations. Nat. Hazards, 75, 57-69. doi:10.1007/s11069- 014-1304-3

7. Nagatani, K., Kiribayashi, S., Okada, Y. (2013). Emergency response to the nuclear accident at the Fukushima Daiichi Nuclear Power Plants using mobile rescue robots. J. Field Robot, 30, 44-63. doi:10.1002/rob.21439

8. Murphy, R. R., Tadokoro, S., Nardi, D. (2008). Search and rescue robotics. In: Siciliano, B., Khatib, O. (Eds.) Springer Handbook of Robotics. Springer, Heidelberg. P. 1151-1173. 
9. Minsky, M. (1980). Telepresence. Omni, 45-50.

10. Ekaterina, R. S., Markus, V., Alexandra, K., Thecla, S., Bernhard, E. R. (2017). Gathering and Applying Guidelines for Mobile Robot Design for Urban Search and Rescue Application. Springer International Publishing AG 2017 M. Kurosu (Ed.): HCI 2017, Part II, LNCS 10272, P. 562-581. doi: 10.1007/978-3-319-58077-7_45

11. Badlou, M. R., Moshiri, B., Najjar A'rabi, B. (2009). Using a rescue robot to reduce human casualties in accidents. Conference on the role of computer engineering in improving the consumption pattern.

12. Hajian, F., Parspour, R., Samadi, M. (2006). The presence of rescue robots in relief and rescue conditions. Third International Congress on Health, Treatment and Crisis Management in Unexpected Events.

13. Mir Mohammad Sadeqi, H., Bastani, H., Azar Nasab, E. (2004). Design and implementation of intelligent rescue robots for search and rescue operations. 12th Iranian Conference on Electrical Engineering.

14. Mohebbi, A., Sepehri, S., Safaei, S., Taghipoor, A. (2010). "HIRAD: Teleoperated Tracked Mobile Robot with Novel Locomotion System For Uneven Terrains". Proceedings of the 1st conference on Dynamics of Advanced Structures, Mechanics Research Center. Isfahan, 23-25 Nov. 2003 (in Persian).

15. Bachelor thesis, A., 2005. "RoboCup Rescue robot". BCH Thesis, University of Higher Education, Newcastle, MA, Nov. URL: http://www.abc.edu (Last accessed: 16.11.2018).

16. Moosavian, A., Semsarilar, H., Kalantari, A. (2006). Design and Manufacturing of a Mobile Rescue Robot. Proceedings of the 2006 IEEE/RSJ International Conference on Intelligent Robots and Systems, Mechanics Research Center. Beijing, 9-15 Oct. 2006 (in China).

17. Jagannathan, S., Lewis, F. L., Kai Liu, (1994). Motion control and Obstacle Avoidance Of a Mobile Robot With an onboard Manipulator. Journal of Inteligent Manufacturing, 1(5), 287-302.

18. Mastersthesis, A. (2010). Modelling Wireless Robots for Urban Search and Rescue in Artificial Rubble. MS Thesis, University of Higher Education. Victoria, MA, May. URL http://www.abc.edu (Last accessed: 16.11.2018).

19. Lima, P. U. (2012). Search and rescue robots: the civil protection teams of the future. In: 2012 Third International Conference on Emerging Security Technologies (EST). P. 12-19.

20. Yanco, H. A., Baker, M., Keyes, B., Thoren, P. (2006). Analysis of human-robot interaction for urban search and rescue. In: Proceedings of PerMIS.

21. Burke, J. L., Murphy, R. R., Coovert, M. D., Riddle, D. L. (2004). Moonlight in miami: field study of human-robot interaction in the context of an urban search and rescue disaster response training exercise. Hum.-Comput. Interact., 19, 85-116. doi:10.1080/07370024.2004.9667341

Стаття надійшла до редакціi / Received 20.12.18

Статтю прорецензовано / Revised 14.06.19

Статтю підписано до друку / Accepted 16.09.19

Мохаммедреза Шаріфібамродуд, Маджид Мафі

Дослідницький центр травм, Університет медичних наук Бакіяталла,

Алея Носраті, Шейх Бахай Саутерн Авеню, Молласадра Стріт, Ванак, Тегеран, Іран,

+98915316 5943, +98912 201 7725, Majid.mafi@gmail.com

РОЗРОБКА Й ВИРОБНИЦТВО РЯТУВАЛЬНОГО РОБОТА

ТА ОЦНКА ЙОГО ЕФЕКТИВНОСТІ ДЛЯ РЯТУВАЛЬНИХ МІСІЙ

Вступ. Щороку стихійні лиха (землетруси, повені, буревії тощо) трапляються по всьому світу та тягнуть за собою загибель багатьох людей. Часто рятувальні місії не можуть вчасно надати допомогу і постраждалі залишаються під завалами тривалий час.

Проблематика. Однією з головних проблем для рятувальників єподолання та усунення перешкод для забезпечення швидкого доступу до травмованих людей, які знаходяться під завалами.

Мета. Розробити та створити рятувального робота з високою швидкістю та точністю роботи та з низькою вартістю для забезпечення оперативного знаходження та рятування поранених під завалами.

Матеріали й методи. Для проектування використано програмне забезпечення САТIA із застосуванням методу кінцевих елементів для потужного аналізу складних деталей; для моделювання механізмів, за допомогою яких створювалися 3D ескізи кожного компонента робота, - програмне забезпечення SOLIDWORKS. B єдину систему компоненти складено з використанням керуючого обладнання. 
Результати. У системі управління роботом використано два центральних процесори - керівний ПК, як головний процесор, і ноутбук, встановлений на робота, як залежний процесор. Загальну конструкцію робота виконано з використанням програмного забезпечення для моделювання SOLIDWORKS, тоді як для проектування роботи механізму - програмне забезпечення CATIA. Щоб подолати складні маршрути, в системі руху робота застосовано гусеницю, а в передню частину робота вбудовано дві «руки» для підйому на перешкоди та нерівні місцевості. Окрім руки, яка обертається, розроблено ще одну робочу руку, використання якої дозволило підвищити здатність робота проходити різними маршрутами.

Висновки. На національних та міжнародних змаганнях було продемонстровано можливості робота в умовах, близьких до реальних. Розробка отримала багато нагород, що свідчить про успіх та фактичні вдосконалення в кожному аспекті його роботи. Ефективність конструкції робота було доведено в Лізі рятувальних роботів, де розробку було оцінено як одну з найкращих конструкцій.

Ключові слова: рятувальний робот, озброєння, міські пошуково-рятувальні місії. 